used to test and modify concepts of electrophilic substitution based in the past on more familiar reactions such as nitration. Incidental observations in the course of Dr. Eaborn's work which attracted considerable attention were the first isolation of an optically active organosilicon compound having a silicon as its single asymmetric centre, and his detection of the mesomorphism of di-isobutylsilane diol, which does not fall into any one of the three classes previously thought adequate for classification of liquid crystals.

Dr. Eaborn's researches involve at present, in addition to extensions of the work mentioned here, a general study of mechanisms of reactions of organometallic compounds, including the effects of highenergy radiation on such compounds, and investigation of the reactivity of fluorene derivatives. Dr. Eaborn is a graduate of the University of Wales, of which he holds the D.Se. degree. He was appointed an assistant lecturer in the (then) University College of Leicester in 1947, promoted lecturer in 1950, and in 1954 was given the title of reader in physical-organic chemistry in recognition of his distinguished work in that field. He has recently been awarded a Robert A. Welch visiting scholarship at the Rice University in Texas, which he expects to take up early in 1962 .

\section{The Falkland Islands Dependencies Survey}

THE R.R.S. Shackleton left Southampton on October 3 for the Falkland Islands Dependencies Survey, 1961-62, taking twenty scientists and technicians of the Survey and two meteorologists for South Georgia. The R.R.S. Shackleton has been extensively used since it was taken over by the Survey in 1955. Earlier this year, using the Shackleton, the Survey was able to collect geological specimens from the Clerke Rocks and to make landings on Visokoi Island (South Sandwich Group), Laskov Island and Vindication Island. During the same voyage, a magnetic survey of the Scotia Arc (the submarine mountain range running from South Georgia through the South Sandwich Group and the South Orkneys to the South Shetlands) was carried out. Mr. Cameron and Mr. Kennett, who were responsible for this survey, hope to take seaborne seismic soundings this season in the same area, extending their magnetic study of the rocks below the ocean floor, with the view of tracing the course of the Are and its connexion with the Andean mountains of South America. Also arranged for the R.R.S. Shackleton is a series of regular observations to check the secular change in the Earth's magnetic field; this investigation is being made at the request of Prof. Takesi Nagata, Tokyo University, on behalf of the International Union of Geodesy and Geophysics.

The purpose of the Falkland Islands Dependencies Survey, the director of which is Sir Vivian Fuchs, is to carry out scientific research in the Antarctic, under the administrative control of the Governor of the Falkland Islands. For nearly seventeen years it has maintained permanent bases on the mainland of Graham Land and on nearby islands. At these bases between ninety and one hundred scientists and technicians spend periods of up to two years carrying out a systematic series of investigations which, so far, have been producing valuable information about the weather and structure of the south polar continent. In addition, numerous investigations are being made in the fields of geophysics and human physiology in Antarctic con- ditions. Each Antarctic summer (November-March) the sea ice clears sufficiently for specially strengthened ships, such as the R.R.S. Shackleton, to make voyages to these bases with relief staff and stores.

\section{Russian Space Research}

RECENT cosmic flights in the U.S.S.R. found their reflexion in the popular scientific journal, Priroda, for 1961. Thus, N. M. Sisakyan $(1,7)$ discusses the biological factors, while space-time problems are discussed by D. A. Frank-Kamenetsky $(1,16)$ and by A. S. Kompaneets $(5,17)$; V. G. Kurt (2, 23) discusses the upper atmosphere and the interplanetary space. V. D. Davydov $(3,3)$ concerns himself with the Earth-Venus flight, and finally in No. 5 (May) of Priroda there is a number of articles dealing with the flight of Y. A. Gagarin on April 12 (pp. 3, 5, 6, 8, 14, 16). The space ship which circumnavigated the Moon on October 7, 1959, automatically photographed the other side of the Moon, and an account of these photographs and of the map constructed of the other side of the Moon are given by Y. N. Lipsky (Priroda, 1, 35; 1961); a map on the scale of $1: 10,000,000$ is appended.

\section{Atomic Energy and its Applications}

Atoomenergie en haar Toepassingen (Atomic Energy and its Applications), the scientific and technical periodical published under the auspices of The Netherlands Reactor Centre (Reactor Centrum Nederland), normally contains articles in Dutch dealing with various aspects of nuclear energy, but the June issue $(3$, No. 6), which is devoted entirely to the activities and achievements of the nuclear industry in The Netherlands, is printed in English for the benefit of a wider public. The introductory article, which is written by Prof. M. Bogaardt, adviser to the Centre, gives a general picture of the industrial activity in the nuclear field in The Netherlands, and is followed by a brief illustrated description of the Centre and a number of short articles contributed by leading Dutch firms. The comprehensive buyers' guide of nuclear and allied products, materials and services-the first of its kind--which concludes the issue, has been compiled from answers received to a questionnaire circulated among a large number of Dutch firms which are actively engaged in the nuclear field. The guide consists of two sections, the first being an alphabetically arranged classified list of products with the names of the respective manufacturers, and the second an alphabetical index of firms and their addresses with brief details of their chief products.

\section{Society for Folk-Life Studies}

A VERY successful conference to inaugurate the Society for Folk-Life Studies was held at University College, London, during September 6-8, 1961. More than eighty people from many parts of Great Britain and Ireland attended and, at a general meeting held on September 8, the Society was formally established. The following officers were elected: President, Dr. Iorwerth C. Peate (Welsh Folk Museum); Vice-President, Mr. Andrew Jewell (University of Reading); Secretary, Mr. J. Geraint Jenkins (Welsh Folk Museum); Treasurer, Mr. Stewart F. Sanderson (University of Leeds). The following members were elected to serve on the Council: Mr. Frank Atkinson (Barnard Castle, Durham); Mr. G. Ewart Evans (Ipswich); Mr. A. T. Lucas (National Museum of Ireland); Mr. B. R. S. Megaw (University of Edin. 